\title{
ELECTRIC AND HEMODYNAMIC EFFECTS OF BETA-BLOCKERS IN PATIENTS WITH LIVER CIRRHOSIS
}

\author{
EUGEN ȚIERANU ${ }^{1}$, IONUȚ DONOIU ${ }^{1}$, OCTAVIAN ISTRĂTOAIE ${ }^{1}$, LOREDANA MARIA \\ ȚIERANU ${ }^{2}$, DAN-IONUT, GHEONEA $^{3}$, TUDOREL CIUREA ${ }^{3}$, ALICE ELENA GHENEA ${ }^{4 *}$, \\ ANCA UNGUREANU ${ }^{4}$
}

\author{
${ }^{1}$ Department of Cardiology, University of Medicine and Pharmacy, Craiova, Romania \\ ${ }^{2}$ Department of Obstetrics and Gynaecology, University of Medicine and Pharmacy, Craiova, Romania \\ ${ }^{3}$ Department of Internal Medicine, University of Medicine and Pharmacy, Craiova, Romania \\ ${ }^{4}$ Department of Bacteriology, Virology and Parasitology, University of Medicine and Pharmacy, Craiova, Romania
}

*corresponding author: gaman_alice@yahoo.com

Manuscript received: January 2020

\begin{abstract}
Acute and chronic heart failure can lead to acute or chronic liver injury through various mechanisms. Treatment in these cases should primarily target heart disease. Patients with advanced liver disease may experience various manifestations at the cardiac level, mainly cardiomyopathies (dilatation cardiomyopathy of alcoholic aetiology, hypertrophic cardiomyopathy). These conditions involve hemodynamic changes, systolic function impairment, diastolic dysfunction, reduced cardiac output (low left ventricular ejection fraction - LVEF) and electrophysiological abnormalities (rhythm disturbances, QT prolongation, driving disturbances). Patients with liver cirrhosis usually have rhythm disturbances (tachycardia, bradycardia). The inability to maintain a high heart rate may later contribute to a reduced cardiac output, insufficient to meet the needs of systemic circulation. Beta-blockers (NSBB) are a class of drugs that are extremely important because of their use in various conditions. Their discovery dates back more than 100 years ago when researchers have launched the idea that the pharmacological action of catecholamines consists in the selective binding of certain receptors for which they have a high selectivity. Beta-blockers with intrinsic sympathomimetic action reduce heart rate at rest, lower than propranolol or metoprolol, but interfere with maintaining adequate heart rate under stress or physical effort.
\end{abstract}

\section{Rezumat}

Insuficiența cardiacă acută şi cronică poate duce la leziuni hepatice acute sau cronice prin diferite mecanisme. Tratamentul în aceste cazuri trebuie să vizeze în primul rând patologia cardiacă. Pacienții cu boală hepatică avansată pot prezenta diverse manifestări la nivel cardiac, în principal cardiomiopatii (cardiomiopatie de dilatare de etiologie alcoolică, cardiomiopatie hipertrofică). Aceste afecțiuni implică modificări hemodinamice, afectarea funcției sistolice, disfuncție diastolică, debit cardiac redus şi anomalii electrofiziologice (tulburări de ritm, prelungirea QT, tulburări de conducere). Pacienții cu ciroză hepatică au de obicei tulburări de ritm (tahicardie, bradicardie). Incapacitatea de a menține o frecvență cardiacă ridicată poate contribui ulterior la reducerea debitului cardiac, insuficientă pentru a răspunde nevoilor circulației sistemice. Be ta-blocantele sunt o clasă de medicamente care sunt extrem de importante datorită folosirii lor în diferite condiții. Descoperirea lor datează de mai bine de 100 de ani, când cercetătorii au lansat ideea că acțiunea farmacologică a catecolaminelor constă în legarea selectivă a anumitor receptori pentru care au o selectivitate ridicată. Beta-blocanele cu acțiune simpatomimetică intrinsecă reduc ritmul cardiac în repaus, într-o măsură mai mică decât propranololul sau metoprololul, dar interferă cu menținerea ritmului cardiac adecvat sub stres sau efort fizic.

Keywords: hemodynamic, rhythm disturbance, liver cirrhosis, beta-blockers

\section{Introduction}

Patients with liver cirrhosis frequently experience autonomic cardiovascular dysfunction manifested by increased sympathetic nervous system activity and reduced cardiac function, with important implications for liver dysfunction and survival [1-3]. The baroreceptor reflex is a determinant of electrical stability in the heart [4-7]. Patients with liver cirrhosis exhibit intense sympathetic nervous system activity and hyperdynamic circulation resulting in increased cardiac output and reduced systemic vascular resistance. These changes may induce myocardial remodelling and left ventricular hypertrophy ( $\mathrm{LVH})$, which may lead to changes in diastolic evolving cardiomyopathy function [8-10].

Chronic liver disease can induce systolic and diastolic dysfunction, electrophysiological changes (QT prolongation), and hemodynamic conditions in the presence of a cirrhotic cardiomyopathy. All this can improve significantly after liver transplantation.

In 1981, Lebrec et al. performed the first randomized clinical trial involving 74 patients with cirrhosis with a history of varicella bleeding. This study demonstrated 
a significant reduction in the bleeding relapse in patients who received propranolol versus placebo [11, 12]. Based on the results of Lebrec's study, interest in the use of nonselective beta-blockers (NSBB) in patients with cirrhosis in order to reduce portal hypertension and prevent complications significantly increased. Beta-blockers with intrinsic sympathomimetic action reduce the heart rate at rest, lower than propranolol or metoprolol, but interfere with maintaining an adequate heart rate under stress or physical effort.

Several randomized studies have confirmed that NSBB is an effective treatment for primary prophylaxis of varicose haemorrhage in patients with oesophageal varices [13].

The effect of NSBB on the prevention of varicella bleeding episodes was assumed to be mediated by several mechanisms that act on hemodynamic changes present in patients with cirrhosis $[13,15]$. Patients with portal hypertension exhibit hyperdynamic circulation characterized by increased cardiac output and splenic blood flow and reduced peripheral vascular resistance and splachtin, associated with increased plasma volume. With increased intrahepatic resistance, this hyperdynamic circulatory status plays an important role in the pathogenesis of portal hypertension and its complications [16]. The most important hemodynamic role of NSBB is the decrease in cardiac output via $\beta 1$ receptors and a splenectonic vasoconstriction achieved through $\beta 2$ receptors, leading to a reduction in portal blood flow $[17,18]$.

The main drawbacks of using NSBB are that $15 \%$ of patients with liver cirrhosis may have absolute or relative contraindications to this class of drugs, and another $15 \%$ may have side effects requiring dose reduction, sometimes even discontinuation of treatment $[14,19,20]$.

The need to evaluate patients' hemodynamic response after administration of NSBB is not clearly established. As mentioned above, longitudinal studies in NSBBtreated patients in both primary and secondary prophylaxis suggested a very low risk of bleeding if there was a decrease in the hepatobiliary pressure gradient by at least $20 \%$ of baseline or $<12 \mathrm{mmHg}$. Patients with such values are considered to be hemodynamically responsive.

\section{Materials and Methods}

The study was conducted at the Medical Clinic I Gastroenterology and Cardiology Clinic of the County Emergency Clinical Hospital, Craiova, Romania, in 2014 - 2017. The study included 112 patients who were assigned to two groups:

Group 1 included 67 patients with a diagnosis of cirrhosis (viral, alcoholic, etc.), clinically stable and hemodynamically (not hospitalized due to liver cirrhosis or any related complications in the last 6 months) with chronic beta blocker (propranolol) or requiring treatment after diagnosis.

Diagnosis of liver cirrhosis was based on: clinical examination, biochemical tests, ultrasound assessment, endoscopic examination and impulse elastography Fibroscan in patients without ascites.

Group 2 consisted in 45 patients with B or C virus viral hepatitis, selected from subjects who had no history of cardiovascular disease and who were routinely examined with 2D echocardiographic parameters and electrocardiograms within normal limits.

Detailed study patients data were recorded and stored in a database. During the study, of the two groups studied, a total of 12 patients were excluded for various reasons.

Informal consent forms were signed by each patient enrolled in the study and approved by the Ethics Committee of the University of Medicine and Pharmacy of Craiova, Romania.

The data obtained were stored in Microsoft Excel ${ }^{\circledR}$ files, and then processed statistically in order to perform a statistical analysis of patients' clinical and paraclinical data. The secondary processing of information the descriptive analysis of the batches of patients according to different parameters, the calculation of the basic statistical parameters, the mean and the standard deviation, their ratio, called the coefficient of variation, their graphic representation and the calculation of the regression coefficient - Excel ${ }^{\circledR}$, using Pivot Tables, Functions-Statistical, Chart, and Data Analysis.

\section{Results and Discussion}

In the study group it was higher percentage of patients with liver cirrhosis $(60 \%)$ compared to those with chronic viral hepatitis (40\%), which is shown below in the Table I.

Table I

Distribution of patients according to their affection

\begin{tabular}{|l|c|c|}
\hline \multicolumn{1}{|c|}{ Affection } & Total & $\%$ \\
\hline Liver cirrhosis & 60 & $60.00 \%$ \\
\hline Chronic viral hepatitis & 40 & $40.00 \%$ \\
\hline Total & 100 & $100.00 \%$ \\
\hline
\end{tabular}

As for the distribution of the liver cirrhosis and chronic viral hepatitis groups depending on the patient's age, greater than or less than 60 years old, we did not identify significant differences, the Chi square test returned $\mathrm{p}=0.566>0.05$ (Table II).

By comparing the distribution of the liver cirrhosis group with chronic viral hepatitis group, depending on the gender of the patients (Table III), we found that there were no significant differences, the result of the Chi square test was $\mathrm{p}=0.869>0.05$. 
Distribution of patients according to their affection and age

\begin{tabular}{|l|c|c|c|}
\hline \multicolumn{1}{|c|}{ Group } & Age $<60$ years & Age $\geq 6$ 60 years & Total \\
\hline Liver cirrhosis & $31(51.67 \%)$ & $29(48.33 \%)$ & $60(100.00 \%)$ \\
\hline Chronic viral hepatitis & $23(57.50 \%)$ & $17(42.50 \%)$ & $40(100.00 \%)$ \\
\hline Total & $54(54.00 \%)$ & $46(46.00 \%)$ & $100(100.00 \%)$ \\
\hline
\end{tabular}

Table III

Distribution of patients according to their affection and gender

\begin{tabular}{|l|c|c|c|}
\hline \multicolumn{1}{|c|}{ Group } & Women & Men & Total \\
\hline Liver cirrhosis & $26(43.33 \%)$ & $34(56.67 \%)$ & $60(100.00 \%)$ \\
\hline Chronic viral hepatitis & $18(45.00 \%)$ & $22(55.00 \%)$ & $40(100.00 \%)$ \\
\hline Total & $44(44.00 \%)$ & $56(56.00 \%)$ & $100(100.00 \%)$ \\
\hline
\end{tabular}

We did not identify significant differences in either systolic blood pressure $(\mathrm{SBP})(\mathrm{p}=0.716)$ or diastolic blood pressure (DBP) $(\mathrm{p}=0.481)$ among patients with liver cirrhosis and chronic viral hepatitis, as outlined in Table IV and Table V.

Table IV

Distribution of patients according to SBP and affection

\begin{tabular}{|l|c|c|}
\hline \multicolumn{1}{|c|}{ SBP (mmHg) } & $\begin{array}{c}\text { Liver } \\
\text { cirrhosis }\end{array}$ & $\begin{array}{c}\text { Chronic viral } \\
\text { hepatitis }\end{array}$ \\
\hline No. & 60 & 40 \\
\hline Mean & 124.25 & 123.00 \\
\hline Standard Deviation & 9.33 & 9.66 \\
\hline \multicolumn{2}{|c|}{ p test Student $=\mathbf{0 . 7 1 6}$ - US } \\
\hline
\end{tabular}

Table V

Distribution of patients according to DBP and affection

\begin{tabular}{|l|c|c|}
\hline \multicolumn{1}{|c|}{ DBP (mmHg) } & $\begin{array}{c}\text { Liver } \\
\text { cirrhosis }\end{array}$ & $\begin{array}{c}\text { Chronic viral } \\
\text { hepatitis }\end{array}$ \\
\hline No. & 60 & 40 \\
\hline Mean & 68.25 & 69.25 \\
\hline Standard deviation & 7.18 & 7.30 \\
\hline \multicolumn{2}{|c|}{ p test Student $=0.481$} \\
\hline
\end{tabular}

SBP is significantly higher in patients with chronic viral hepatitis than in patients with liver cirrhosis at the 6 months evaluation, the result of the Student test was $p=0.033<0.05$. This fact can be explained by the role of beta-blockers in reducing blood pressure. The patients included in the group with liver cirrhosis received beta-blockers during the past 6 months.

Table VI

Distribution of patients according to SBP evaluation at 6 months and affection

\begin{tabular}{|l|c|c|}
\hline $\begin{array}{c}\text { SBP after 6 months } \\
(\mathbf{m m H g})\end{array}$ & $\begin{array}{c}\text { Liver } \\
\text { cirrhosis }\end{array}$ & $\begin{array}{c}\text { Chronic viral } \\
\text { hepatitis }\end{array}$ \\
\hline No. & 60 & 40 \\
\hline Mean & 117.50 & 121.25 \\
\hline Standard deviation & 8.76 & 9.98 \\
\hline p test Student & 0.0334 & $\mathrm{~S}$ \\
\hline \multicolumn{2}{|r|}{ p test Student $\mathbf{= 0 . 0 3 3 4}-\mathbf{S}$} \\
\hline
\end{tabular}

We found that the heart rate was significantly higher in patients with liver cirrhosis than patients with chronic viral hepatitis $(\mathrm{p}=0.0057<0.05)$, this is shown in Table VII.

Table VII

Distribution of patients according to their heart rate and affection

\begin{tabular}{|l|c|c|}
\hline Heart rate (bpm) & $\begin{array}{c}\text { Liver } \\
\text { cirrhosis }\end{array}$ & $\begin{array}{c}\text { Chronic viral } \\
\text { hepatitis }\end{array}$ \\
\hline No. & 60 & 40 \\
\hline Mean & 78.85 & 74.45 \\
\hline Standard deviation & 7.36 & 8.00 \\
\hline p test Student & 0.0057 & $\mathrm{~S}$ \\
\hline \multicolumn{2}{|c|}{ p test Student $\mathbf{0 . 0 0 6}$ - S } \\
\hline
\end{tabular}

We found a statistically significant difference between the heart rate value at 60 minutes between the two patient groups (Table VIII), those with liver cirrhosis after beta-blocker administration had a lower, comparative heart rate with those with chronic viral hepatitis who had a higher heart rate $(\mathrm{p}=0.016<0.05)$.

Table VIII

Distribution of patients according to their heart rate at 60 minutes and affection

\begin{tabular}{|l|c|c|}
\hline $\begin{array}{c}\text { Heart rate at 60 min } \\
\text { (bpm) }\end{array}$ & $\begin{array}{c}\text { Liver } \\
\text { cirrhosis }\end{array}$ & $\begin{array}{c}\text { Chronic viral } \\
\text { hepatitis }\end{array}$ \\
\hline No. & 60 & 40 \\
\hline Mean & 69.63 & 74.45 \\
\hline Standard deviation & 7.18 & 8.00 \\
\hline p test Student & 0.0162 & $\mathrm{~S}$ \\
\hline \multicolumn{2}{|c|}{ p test Student $\mathbf{= 0 . 0 1 6}-\mathbf{S}$} \\
\hline
\end{tabular}

Table IX

Distribution of patients according to their heart rate at 6 months and affection

\begin{tabular}{|l|c|c|}
\hline $\begin{array}{c}\text { Heart rate at } 6 \text { months } \\
(\mathbf{b p m})\end{array}$ & $\begin{array}{c}\text { Liver } \\
\text { cirrhosis }\end{array}$ & $\begin{array}{c}\text { Chronic } \\
\text { viral } \\
\text { hepatitis }\end{array}$ \\
\hline No. & 60 & 40 \\
\hline Mean & 60.73 & 73.93 \\
\hline Standard deviation & 5.84 & 6.86 \\
\hline p test Student & $<0.0001$ & HS \\
\hline \multicolumn{3}{|c|}{ p test Student $=<\mathbf{0 . 0 0 0 1}-$ HS } \\
\hline \multicolumn{2}{|c|}{}
\end{tabular}


Also, in the evaluation of patients in the two groups studied at 6 months (patients with chronic hepatic cirrhosis with beta-blocker medication and those with chronic viral hepatitis without beta-blocker), we found a statistically significant difference between the frequency value (Table IX), this was higher in those with chronic viral hepatitis $(\mathrm{p}<0.001)$.

Non-selective beta-blockers (NSBB) are commonly used to prevent portal hypertension and bleeding in patients with liver cirrhosis. In recent years, the use of NSBB in patients with advanced liver disease is controversial (decompensated liver cirrhosis, refractory ascites), mainly due to increased mortality risk and worsening of systemic haemodynamic. In addition, although NSBB has been reported to be associated with a high risk of hypotension, renal failure and infections in patients with severe hepatic impairment, their use has been associated with reducing the risk of spontaneous bacterial peritonitis, alteration of intestinal permeability and reduction of bacterial translocation.

Liver cirrhosis is one of the leading causes of global mortality, and hepatocellular carcinoma and portal hypertension complications are the most common cause of death.

Portal hypertension is characterized by a hyperdynamic systemic circulation with increased cardiac output and heart rate, as well as by lowering the mean blood pressure and systemic vascular resistance [21]. The portal hypertension degree correlates with the severity of hyperdynamic circulation, while a hemodynamic balance is associated with a better prognosis (e.g. a preserved heart rate) [22].

Ascites, oesophageal varices, encephalopathy and/or jaundice are the main features of decompensated liver cirrhosis. Ascites is the main clinical sign of decompensation in $30 \%-50 \%$ of patients. Its occurrence has an incidence of about $50 \%$ within 10 years [23]. Refractory ascites occur in 5\% to $10 \%$ of cases, which significantly reduces the survival time. Oesophageal varices occur in about $50 \%$ of patients with liver cirrhosis [24], the incidence of first bleeding is $12 \%$ $15 \%$ per year, and mortality of $15 \%-20 \%$ for each bleeding episode [25]. Oesophageal varices develop primarily due to high port hypertension, but Fernandez et al. [26] reported that their formation was also modulated by active angiogenesis rather than by a simple mechanism of vasodilation.

External factors, such as surgery, bacterial infections or bleeding of any cause, may be severe triggering factors of the hemodynamic imbalance. Phillip et al. [27] demonstrated that removing more than $5 \mathrm{~L}$ of ascites fluid resulted in a significant reduction in mean blood pressure and peripheral vascular resistance, which is usually associated with an increase in heart rate.

NSBB reduces portal flow and portal hypertension by lowering heart rate (by their effect on $\beta 1$ receptors) and by achieving spleen vasoconstriction (effect on $\beta 2$ receptors) [28]. Several randomized studies have confirmed that the use of NSBB in combination with endoscopic ligation is the preferred primary option in the primary prophylaxis of oesophageal reflux cases [29].

Identifying the haemodynamic response to NSBB remains a challenge for hepatologists. Heebøll et al. [30] demonstrated that only 51 out of 124 (approx.. $40 \%$ ) of liver cirrhosis patients who had portal gradient measurements showed a significant hemodynamic improvement (reduction of more than $20 \%$ or $>12$ $\mathrm{mmHg}$ ) after use of NSBB. Furthermore, the authors did not demonstrate a significant association between portal gradient improvement and heart rate modulation $(\mathrm{p}=0.8)$, which is commonly used to optimize propranolol treatment.

Serstè et al. [31] showed for the first time in 2010 that the mean survival was extremely low in 151 patients with decompensated liver cirrhosis (refractory ascites) treated with propranolol; other factors associated with higher mortality were: the Child-Pugh class (significantly higher mortality in class $C$ patients), hyponatremia and renal failure. These data have raised more concerns among hepatologists about the use of NSBB in patients with advanced liver cirrhosis [32-34]. The relationship between NSBB and haemodynamic involvement was explained by a reduced mean blood pressure, which is a known prognostic factor for hyperdynamic circulation and progression of hepatic disease [35]. For example, in the study by Serstè et al. [31], the cohort that received propranolol had a lower mean blood pressure (90 mmHg vs. $83 \mathrm{mmHg}$ ). However, acute intravenous administration of NSBB has not been shown to reduce the mean blood pressure. The negative effects observed by the authors may be due to the side effects associated with the dose of propranolol. Heart rate is not usually reduced by administering NSBB [36].

\section{Conclusions}

The results of the study indicate that liver cirrhosis, irrespective of its aetiology, affects all social categories without being influenced by the intellectual level of the patients or their social status, resulting in important social and economic consequences.

In this study, we found that heart rate was significantly higher in patients with cirrhosis than patients with chronic viral hepatitis. Although we noticed a slight increase in cardiac frequency with the worsening of the stage of liver cirrhosis, we cannot talk about significant differences between the three classes of severity.

The results obtained in the study did not show any significant differences with respect to both SBP and DBP among patients with liver cirrhosis treated with beta-blockers and those with chronic viral hepatitis. 
Conflict of interest

The authors declare no conflict of interest.

\section{References}

1. Valeriano V, Funaro S, Lionetti R, Riggio O, Pulcinelli G, Fiore P, Masini A, De Castro S, Merli M, Modification of cardiac function in cirrhotic patients with and without ascites. Am J Gastroenterol., 2000; 95(11): 3200-3205.

2. Ates F, Topal E, Kosar F, Karincaoglu M, Yildirim B, Aksoy Y, Aladag M, Harputluoglu MM, Demirel U, Alan H, Hilmioglu F, The relationship of heart rate variability with severity and prognosis of cirrhosis. Dig Dis Sci., 2006; 51(9): 1614-1618.

3. Frățilă O, Mihele AI, Hodisan-Pap EF, Hocopan SC, Brata R, Iliaș T, Comparative hepatoprotective efficacy of silymarin-phyllanthus-choline combination versus silymarin alone in liver diseases with different destruction and inflammation stages. Farmacia, 2020; 68(2): 299-306.

4. Milan A, Caserta MA, Del Colle S, Dematteis A, Morello F, Rabbia F, Mulatero P, Pandian NG, Veglio $\mathrm{F}$, Baroreflex sensitivity correlates with left ventricular morphology and diastolic function in essential hypertension. J Hypertens., 2007; 25(8): 1655-1664.

5. Lantelme P, Khettab F, Custaud MA, Rial MO, Joanny C, Gharib C, Milon H, Spontaneous baroreflex sensitivity: toward an ideal index of cardiovascular risk in hypertension?. J Hypertens., 2002; 20(5): 935-944.

6. Okada N, Takahashi N, Yufu K, Murozono Y, Wakisaka O, Shinohara T, Anan F, Nakagawa M, Hara M, Saikawa $\mathrm{T}$, Baroreflex sensitivity predicts cardiovascular events in patients with type 2 diabetes mellitus without structural heart disease. Circul J., 2010; 74(7): 1379-1383.

7. Yufu K, Takahashi N, Okada N, Wakisaka O, Shinohara T, Nakagawa M, Hara M, Yoshimatsu H, Saikawa T, Gender difference in baroreflex sensitivity to predict cardiac and cerebrovascular events in type 2 diabetic patients. Circul J., 2011; 75(6): 1418-1423.

8. Mircoli L, Rivera R, Bonforte G, Fedele L, Genovesi $\mathrm{S}$, Surian M, Ferrari AU, Influence of left ventricular mass, uremia and hypertension on vagal tachycardic reserve. J Hypertens., 2003; 21(8): 1547-1553.

9. Møller S, Henriksen JH, Cirrhotic cardiomyopathy: a pathophysiological review of circulatory dysfunction in liver disease. Heart, 2002; 87(1): 9-15.

10. Braverman AC, Steiner MA, Picus D, White H, Highoutput congestive heart failure following transjugular intrahepatic portal-systemic shunting. Chest, 1995; 107(5): 1467-1469.

11. Lebrec D, Nouel O, Corbic M, Benhamou JP, Propranolol a medical treatment for portal hypertension?. Lancet, 1980; 2(8187): 180-182.

12. Lebrec D, Poynard T, Hillon P, Benhamou JP, Propranolol for prevention of recurrent gastrointestinal bleeding in patients with cirrhosis: a controlled study. N Engl J Med., 1981; 305(23): 1371-1374.

13. Bernard B, Lebrec D, Mathurin P, Opolon P, Poynard $\mathrm{T}$, Beta-adrenergic antagonists in the prevention of gastrointestinal rebleeding in patients with cirrhosis: a meta-analysis. Hepatology, 1997; 25(1): 63-70.
14. Burcea-Dragomiroiu GTA, Ginghină O, Miron DS, Bârcă M, Popa DE, Hîrjău M, Lupuleasa D, Rădulescu ŞF, The influence of splitting on the in vitro release of metoprolol succinate from scored tablets. Farmacia, 2015; 63(2): 280-285.

15. García-Pagán JC, Escorsell A, Moitinho E, Bosch J, Influence of pharmacological agents on portal hemodynamics: basis for its use in the treatment of portal hypertension. Semin Liver Dis., 1999; 19(4): 427-438.

16. Bosch J, Pizcueta P, Feu F, Fernández M, GarcíaPagán JC, Pathophysiology of portal hypertension. Gastroenterol Clin North Am., 1992; 21(1): 1-14.

17. D'Amico G, Pagliaro L, Bosch J, Pharmacological treatment of portal hypertension: an evidence-based approach. Semin Liver Dis., 1999; 19(4): 475-505.

18. Kroeger RJ, Groszmann RJ, The effect of the combination of nitroglycerin and propranolol on splanchnic and systemic hemodynamics in a portal hypertensive rat model. Hepatology, 1985; 5(3): 425-430.

19. Longacre AV, Imaeda A, Garcia-Tsao G, Fraenkel L, A pilot project examining the predicted preferences of patients and physicians in the primary prophylaxis of variceal hemorrhage. Hepatology, 2008; 47(1): 169-176.

20. Bolognesi M, Balducci G, Garcia-Tsao G, Complications in the medical treatment of portal hypertension. In: de Franchis R ed. Portal Hypertension III: Proceedings of the Third Baveno International Consensus Workshop on Definitions, Methodology, and Therapeutic Strategies. Blackwell Science, Oxford; 2001: 180-201.

21. Møller S, Henriksen JH, Cirrhotic cardiomyopathy. J Hepatol., 2010; 53(1): 179-190.

22. Møller S, Hobolth L, Winkler C, Bendtsen F, Christensen E, Determinants of the hyperdynamic circulation and central hypovolaemia in cirrhosis. Gut, 2011; 60: 1254-1259.

23. Pessione F, Ramond MJ, Peters L, Pham BN, Batel P, Rueff B, Valla DC, Five-year survival predictive factors in patients with excessive alcohol intake and cirrhosis. Effect of alcoholic hepatitis, smoking and abstinence. Liver Int., 2003; 23(1): 45-53.

24. European Association for the Study of the Liver, EASL clinical practice guidelines on the management of ascites, spontaneous bacterial peritonitis, and hepatorenal syndrome in cirrhosis. J Hepatol., 2010; 53: 397-417.

25. D'Amico G, Garcia-Tsao G, Pagliaro L, Natural history and prognostic indicators of survival in cirrhosis: a systematic review of 118 studies. J Hepatol., 2006; 44(1): 217-231.

26. Fernandez M, Vizzutti F, Garcia-Pagan JC, Rodes J, Bosch J, Anti-VEGF receptor-2 monoclonal antibody prevents portal-systemic collateral vessel formation in portal hypertensive mice. Gastroenterology, 2004; 126(3): 886-894.

27. Phillip V, Saugel B, Ernesti C, Hapfelmeier A, Schultheiß C, Thies P, Mayr U, Schmid RM, Huber W, Effects of paracentesis on hemodynamic parameters and respiratory function in critically ill patients. $B M C$ Gastroenterol., 2014; 14: 18: 1-7.

28. Kroeger RJ, Groszmann RJ, Increased portal venous resistance hinders portal pressure reduction during the administration of beta-adrenergic blocking agents 
in a portal hypertensive model. Hepatology, 1985; 5(1): 97-101.

29. Hayes PC, Davis JM, Lewis JA, Bouchier IA, Metaanalysis of value of propranolol in prevention of variceal haemorrhage. Lancet, 1990; 336: 153-156.

30. Heebøll S, Villadsen GE, Aagaard NK, Grønbæk H, Vilstrup H, Keiding S, Propranolol treatment of portal hypertension in cirrhosis patients is better the higher the untreated pressure: a single-centre prospective experience. Scand J Gastroenterol., 2013; 48(8): 969-973.

31. Sersté T, Melot C, Francoz C, Durand F, Rautou PE, Valla D, Moreau R, Lebrec D, Deleterious effects of beta-blockers on survival in patients with cirrhosis and refractory ascites. Hepatology, 2010; 52(3): 1017-1022.

32. Efe C, Purnak T, Ozaslan E, The deleterious effects of propranolol on patients with cirrhosis. Hepatology, 2011; 53(1): 371-372.
33. Wong F, Salerno F, Beta-blockers in cirrhosis: friend and foe?. Hepatology, 2010; 52(3): 811-813.

34. Senzolo M, Nadal E, Cholongitas E, Burroughs AK, Is hydrophobia necessary for the hepatologist prescribing nonselective beta-blockers in cirrhosis?. Hepatology, 2011; 53(6): 2149-2150.

35. Llach J, Ginès P, Arroyo V, Rimola A, Titó L, Jiménez W, Gaya J, Rivera F, Rodés J, Prognostic value of arterial pressure, endogenous vasoactive systems, and renal function in cirrhotic patients admitted to the hospital for the treatment of ascites. Gastroenterology, 1988; 94(2): 482-487.

36. Villanueva $\mathrm{C}$, Albillos $\mathrm{A}$, Genescà $\mathrm{J}$, Abraldes JG, Calleja JL, Aracil C, Bañares R, Morillas R, Poca M, Peñas B, Augustin S, Garcia-Pagan JC, Pavel O, Bosch J, Development of hyperdynamic circulation and response to $\beta$-blockers in compensated cirrhosis with portal hypertension. Hepatology, 2016; 63(1): 197-206. 